\title{
National Policy on Education: Problems and Prospects for Teaching and Learning of Igbo as a Second Language in Nigerian Secondary Schools
}

\author{
Afoma R. Okudo \\ Department of Arts and Social Sciences Education, Faculty of Education, \\ University of Lagos, Nigeria \\ E-mail: afomao@rocketmail.com; aokudo@unilag.edu.ng
}

Tel: 08025201690

\section{Doi:10.5901/jesr.2013.v3n2p371}

\begin{abstract}
This study looks into the teaching and learning of lgbo as second language in some selected secondary schools in Lagos State, Nigeria against the background of the Nigerian National Policy on Education (2004) which established the teaching of second Nigerian languages in secondary schools. Survey research design involving questionnaire, observation and oral interview was used to obtain data from eighty junior secondary school students and four lgbo language teachers from four secondary schools. Based on the findings of the study, suggestions and recommendations were proffered for the concerned stakeholders to enhance the successful teaching of Igbo L2 in order to fulfill the recommendations of the Nigerian Policy on Education pertaining second language education.
\end{abstract}

\section{Background To Study}

There are approximately 7000 languages in existence (UNESCO, 2003), Nigeria has two broad groups of languages - indigenous and exogenous languages. Exogenous languages are those that are foreign such as, English, French, Arabic, while the number of Nigerian languages is put at about five hundred and twenty - one (521). This number includes 510 living languages, two languages without native speakers and 9 extinct languages (Crozier \& Blench, 1992; Ikegbunam, 2010). Hausa, Igbo and Yoruba are considered the Nigeria's major languages due to their having speakers in excess of 18 million each, while the rest are referred to as minority languages. Again, these languages have been grouped into three main language families, thus Nilo Saharan family, Asiatic family and Niger Congo family, e.g. Igbo, Fulani, Yoruba Edo,etc.(GreenBerg, 1996).However, most of the three major Nigerian languages belong to Niger Congo family - Igbo, Yoruba and Hausa, - and were chosen to be the three major Nigerian languages because they are spoken by over ten million people each(Crozier and Blench 1992).Among the exogenous languages - English, French and Arabic - English is the official language. It has been in Nigeria since 1842 that is before the coming of the British missionaries to Nigeria. It has been discovered that English has increasingly replaced Nigerian languages and is widely used in business, academics, and everyday life activities especially in the cities. English language also became institutionalized because it is the language of Nigerian's colonial masters and was imposed on the people.

This is really a serious challenge and the situation is making Nigerian children to no longer be inheritors but survivors of social and cultural heritage. This portends a cultural catastrophe for the country which demands serious concern by all Nigerians (Ohiri - Aniche, 2000; Obe, 1980).

Based on these circumstances surrounding Nigerian languages and their importance, the National Policy on Education's statement indicates the development of two pedagogical approaches in the teaching and learning of any Nigerian languages - L1 and L2. Again, it was recommended that the Junior Secondary School students should study one of these languages Igbo, Hausa, Yoruba as second Language. However, this does not appear to be the practice.

\section{Problem Of The Study}

Many problems seem to hinder the proper implementation of teaching Igbo language as a second language. 
For instance, there are inadequate instructional materials to carry out the teaching and learning of Igbo as second language. The available textbooks are mainly the ones written for teaching Igbo as L1.

The methods of teaching and learning of Igbo L2 stipulated are either not appropriate or adequate. Also the teaching methods are not activity - oriented. Activities such as role play, songs and games, visits and excursion of which could lead to a better acquisition of communication competence in Igbo and promotion of better appreciation of Igbo culture in the Igbo L2 learners are neglected

Therefore, this study intends to look into, highlight and suggest ways of making available the instructional materials and improving the teaching methods/techniques of Igbo as a second language in junior secondary school classes in Lagos State as well as other urban cities in Nigeria.

\section{Theoretical Framework}

Constructivism theory of Learning will guide this study. The theory is based on the principles that knowledge is constructed by an active learner; and that knowledge is socially constructed. For the constructivist, knowledge is not transmitted from an expert or teacher to a passive recipient, the learner. Rather, it results from a cognitive activity of meaning - construction. The learner is engaged in the construction of mental representations of the material to which he or she is exposed, and to make sense of it. Knowledge therefore results from the activity taken by the learner usually in a problem - solving activity, and from reflections on those actions. The main feature of constructivist theory is that it focuses on the learner; learners take responsibility for learning; they become architects of their learning process; the environment is learner - centred (Adriaen 2002), the teacher must mediate between learner's current and emergent understanding. He or she becomes a guide, a coach, a facilitator, and emphasis will be higher - order cognitive skills. The need to focus on the communication function of language as much as its structural grammatical properties can be achieved with properly designed exercises fostering knowledge construction, critical thinking, problem - solving etc. When it comes to language teaching, Adriaen(2002) asserts that the use of technology in language teaching and learning still has to deliver on the pedagogical benefits vaunted by its enthusiasts. And there needs to be a shift to technology to support learner goals. This supports the teaching of Igbo L2 to support learner goals by using technology like audio visual aids, language laboratories, radios etc.

And to focus on the communication of Igbo L2, as stipulated in the Nigerian National Policy on Education, there should be designed exercises fostering knowledge construction, problem - solving and it should be activity - oriented so as to make it learner - centred. In the classroom environment, the social construction of meaning should be achieved by collaborative work and social discussion among learners. Hence the Igbo L2 learners need to go for excursions to Igbo land so as to interact with the Igbo native speakers and dialogue with them because learning does not occur in isolation but rather with community.

\section{Significance of Study}

This study will help the government to realize her educational goals concerning the teaching of Nigerian languages as L2 when the students from different ethnic backgrounds start to interact and relate closely as a result of joy derived from studying together. It will help in attracting the interest of other students who never wanted to learn Igbo L2 especially when the teachers make use of appropriate teaching aids and teaching methods.

Publishers and authors will realize the need to produce credible Igbo L2 textbooks to enhance the teaching and learning of Igbo as a second language.

\section{Research Questions}

Research questions guiding this study are:

Do teachers use appropriate teaching methods in delivering the lessons in the Igbo L2 curriculums?

Are there adequate instructional materials for the implementation of Igbo L2 curriculum? 


\section{Methodology}

This study was carried out in the four secondary schools in the Mainland Local Government Area of Lagos State in Nigeria. This study was conducted using a survey design. This is because a survey provided data to describe the existing conditions at particular points in time. It is also appropriate for research questions about self reporting beliefs or behaviours. It is strongest when the answers to questions by respondents measure variables as in this research.

The instruments for data collection involved questionnaire, class observation and oral interview to obtain data from eighty junior secondary school students and four Igbo language teachers.

As for teaching Igbo as a second language, questionnaire was used in this study to obtain information which was used to answer questions that have been asked, to solve problems, to assess needs and set goals, to determine whether or not specific objectives have been achieved, to analyze trends across time, and generally to describe what exists, in what amount, and in what context (Isaac \& Michael, 1983). The validity of the questionnaire was obtained on expert opinion of two senior professors. While the main purpose of oral interview is to gather relevant information concerning events, work results, knowledge, opinions, perspectives, values, attitudes, and others in face to face contacts (Kubr \& Prokopenko, 1989).And classroom observation technique was used to validate other data gathering methods like interview and questionnaire, and the observer was as un - obtrusive as possible so as to make it be very useful (Leatherman, 1990).

The essence of the study was to carry out an investigation in the level of implementation of the Igbo as second language curriculum under the current system of education that is being practiced in Nigeria. In order to carry out an objective study, the researcher constructed 2 sets of questionnaire with ten - item statements each - both for teachers and for students. They were administered to Igbo students and teachers in 4 randomly selected secondary schools in Lagos state of Nigeria (Colleges A, B, C, and D). They were selected because not all secondary schools in Lagos State teach Igbo language as one of their subjects. Four (4) Igbo teachers were selected from the 4 colleges while 20 students of Igbo language were selected from each of the college, to make a total of 80 students of Igbo language that were used for the study. The questionnaire adopted the $4-$ point Likert scale.

\section{Results}

The analyses that are reported on in this section include descriptive statistics for correlations among the major study variables. All significance tests used an alpha level of 0.05 .

Item 3 of the student questionnaire was used to measure the availability of textbooks and instructional materials in Igbo L2 while item 2 was used to measure the teaching methods of implementing Igbo L2 curriculum. Their cross tabulation was carried out and the result is shown below:

Table 1: Cross tabulation of availability of textbooks and implementation of curriculum

\begin{tabular}{|c|c|c|c|c|c|c|}
\hline & & \multicolumn{4}{|c|}{$\begin{array}{l}\text { There are sufficient text books on Igbo } L 2 \text { in } \\
\text { the school library. }\end{array}$} & \multirow[b]{2}{*}{ Tota } \\
\hline & & $\begin{array}{l}\text { strongly } \\
\text { disagree }\end{array}$ & Disagree & Agree & $\begin{array}{l}\text { strongly } \\
\text { agree }\end{array}$ & \\
\hline $\begin{array}{l}\text { my Igbo teachers } \\
\text { always engage us in } \\
\text { wide variety of class } \\
\text { activities }\end{array}$ & $\begin{array}{l}\text { Disagree } \\
\text { Agree } \\
\text { strongly agree }\end{array}$ & $\begin{array}{l}0 \\
19 \\
4\end{array}$ & $\begin{array}{l}3 \\
31 \\
4\end{array}$ & $\begin{array}{l}0 \\
15 \\
0\end{array}$ & $\begin{array}{l}0 \\
0 \\
4\end{array}$ & $\begin{array}{l}3 \\
65 \\
12\end{array}$ \\
\hline \multicolumn{2}{|l|}{ Total } & 23 & 38 & 15 & 4 & 80 \\
\hline
\end{tabular}

All the 3 respondents that disagreed with their teachers engaging them in a wide variety of class activities disagreed that there are sufficient textbooks in the school library. For the 65 who agreed that Igbo teachers 
engage them in a wide variety of class activities, 19 strongly disagreed, 31 disagreed and the remaining 15 agreed that there are sufficient Igbo textbooks in the school library. For the 12 who strongly agreed that their teacher engage them in a variety of class activities, 4 strongly disagreed, 4 disagreed while the remaining 4 strongly disagreed that there are sufficient textbooks on Igbo as second language in the school library. The chisquare was carried out and the result is presented in the table below;

Table 2: Chi-square of the adequate textbooks and implementation of Igbo language L2 curriculum

\begin{tabular}{|l|l|l|l|}
\hline & Value & df & $\begin{array}{l}\text { Asymp. Sig. (2- } \\
\text { sided) }\end{array}$ \\
\hline Pearson Chi-Square & $29.332(\mathrm{a})$ & 6 & .271 \\
$\begin{array}{l}\text { Likelihood Ratio } \\
\text { Linear-by-Linear }\end{array}$ & 25.103 & 6 & .000 \\
$\begin{array}{l}\text { Association } \\
\text { N of Valid Cases }\end{array}$ & 1.673 & 1 & .196 \\
\hline
\end{tabular}

Since the p-value $(0.271)$ is greater than the level of significance at which the test was carried out, it implies that the null hypothesis be accepted which implies that available textbooks / materials are not adequate for the implementation of Igbo language L2 curriculum

\section{Analysis of Teachers' Questionnaire}

For the questions designed for the teachers, the responses are as follows: -

1 One of the teachers has B. A. in Igbo; others have B. A.ED, TC II and NCE. This shows that the teachers are well qualified to teach Igbo except that out of the four teachers, only one has been exposed to the Igbo L2 teaching methods.

2 It was discovered that all the Igbo teachers use Igbo L1 curriculum and its pedagogy in teaching Igbo. None of the teachers is aware of the new Igbo L2 curriculum as well as its teaching methods for junior secondary schools. The syllabus they use is the one extracted from Igbo L1 syllabus, which is termed Lagos State Unified Scheme.

3 They all agreed that they do not have any Igbo L2 textbooks. One of the teachers gave the reason that Igbo is not actually taught as L2 in her school. Actually, there is no separate class for the Igbo L1 and Igbo L2 in Lagos state schools except in college D where they teach it only in JSS1

4 Most of the teachers use objects in the class to teach because their schools do not have language laboratory. Only one teacher whose school has language laboratory uses radio.

\section{Oral Interview With Classroom Observation Conducted For Teachers.}

The following questions were asked:

1 Do students show interest in Igbo language study?

2 Why are you not using the new Igbo L2 curriculum to teach the Igbo students?

\section{Teachers' Oral Interview Analysed}

Below are the responses to the oral interview conducted for teachers:-

1 It was observed that the teachers find it difficult teaching Igbo as second language in Lagos State and the also confirmed that most of the students do not like to be seen speaking Igbo. This is because the language of the environment often takes upper hand in their interaction with other students. Moreover, most parents do not approve its study. 
2 Three of the teachers expressed surprise at the mention of new Igbo L2 curriculum while only one is aware of it.

3 The teachers said that since the school authority gives them unified scheme, there is nothing they can do about it. Secondly, they have not seen the Igbo L2 curriculum in question.

\section{Summary of Findings}

The researcher's major findings are as follows:

1 At College D students now study Igbo L2 only in JSS 1 and JSS2 as registering it in Junior Secondary School Certificate Examinations no longer holds.

2 In most schools visited especially those that study Igbo language, teachers do not use Igbo L2 curriculum. Most teachers are not even aware of its existence. Hence, they do not use the appropriate teaching methods for teaching Igbo language to non - native speakers as stipulated by the Nigerian National Policy on Education for teaching and learning of second Nigerian languages in secondary schools. For instance, in teaching communicative skills especially speaking and listening, teachers do not use appropriate methods and teaching aids which will enhance effective learning of the language by non - native speakers of the Igbo language.

3 There are inadequate textbooks and instructional materials, no language laboratory for the proper implementation of Igbo L2 curriculum in the schools except in College D.

\section{Conclusion}

The major hindrances towards the proper methods of teaching Igbo L2 have been highlighted. Unless schools with the instruction of Government ensure the implementation of the Nigerian National Policy on Education's statement about the teaching and learning of Nigerian language as L2 in secondary schools, its teaching of course will continue to be done haphazardly.

Appropriate teaching and learning of Igbo L2 may not be carried out unless teachers are exposed to the new Igbo L2 curriculum with its appropriate teaching methods as outlined in the study. Also, adequate instructional materials should be made available for the proper implementation of the programme.

The syllabus in use as observed during the study in most colleges still remains the one extracted from the 1982 Igbo L1 curriculum which is termed Lagos State Unified Scheme. In other words, some schools in the Lagos State do not yet use the new Igbo L2 curriculum produced by the Nigerian Education Research and Development Council (NERDC, 1999).

In the classrooms, it was also observed that the categories of students for Igbo $L 2$ are native and non native speakers, whereas the classes are supposed to be meant for only Igbo L2 students, that is non - native speakers of Igbo. This problem of mixed ability can neither assist in the development of effective communicative skills in Igbo nor adequately help in realizing the Igbo L2 objectives which entails: national unity and promotion of social interaction; developing students' intellectual powers through the study of another language; to provide students with skills that will enable them communicate orally and to some extent in writing, in personal career context with speakers of another language and with people of other nationalities who have also learned the language, etc(NPE,2004 section 1:9E)

\section{Recommendations}

In view of the findings of this study, the following recommendations are hereby made: -

Teachers should always go for seminars and workshops to acquire the new trends in teaching of Igbo language. There, they can know about new innovations pertaining their teaching subject, new curriculum or if there is revision in the existing one, current textbooks in use and how to get them.

Teachers should make the lessons interesting by using real objects in teaching and involve activity oriented method. Getting Igbo films for their students to watch, through that, the students can be motivated and interested in the Igbo L2 learning. The teacher can ask the students questions based on a particular film 
watched. They can be asked to act it out among themselves creating opportunity for role plays. In this form, psychomotor domain is taking care of the four language skills.

Teachers can observe the students by keeping the records of Igbo class attendance during lessons. Students can be encouraged to have interest when records of their performances and participation in class are kept.

Government should ensure that the policy statement concerning the teaching of Nigerian languages as L2 is implemented in Lagos State schools as the mixing up of L1 and L2 does not give room for students to actually learn and use the language.

Relevant textbooks should be approved and provided for use by the government.

Government should arrange for Nigerian language seminars and in - service training for the teachers especially Igbo $L 2$ teachers. This gathering will enhance the teaching of Igbo $L 2$ and make the language teacher aware of any new trends in the study of the language.

Parents should buy textbooks for their children. They should encourage their children more by speaking Igbo language to their children and also telling them to speak the language always especially at home.

Students' interests will develop if parents support their studying of the subject.

Society should encourage the Nigerian language learning by accepting the speaking of the language in meetings, business, academic environments, neighbourhoods etc. Students of Igbo language should not be ridiculed about it so as not to develop low self - esteem.

\section{References}

Akande, M.O. (1985).Hints on Teaching Practice and General Principles of Education. Lagos. Osko Publishers. Crozier, D. and Blench, R.(eds)(1992). An Index of Nigerian Languages. Dallas Texas: Summer Institute of Linguistics. Federal Ministry of Education (1982) Junior Secondary School Curriculum for Igbo, Hausa, Yoruba. Lagos: NERDC. ----- (1977 revised1981, 1998,2004). National Policy on Education. Lagos: Federal Ministry of Information.

Federal Republic of Nigeria (1973). National Secondary Education CurriculumWorkshop $19^{\text {th }}-23^{\text {rd }}$ Sept. NERC: Lagos: Lagos: Federal Ministry of Information.

Green Berg,J.(1963). The Language of Africa. The Hague: Monton: Indiana University Press

Hornby,A.S.(2000).Oxford Advanced Learners Dictionary of Current English. New York: Oxford University Press.

Igwe, R.O. (2000).Fundamentals of Curriculum and Instructions. Lagos. Sunshine InternationalPublications Nigeria Limited.

Ikegbunam, C.I. (2009). 'Closing the gaps in Policy Implementation: The Case of Nigerian Languages' in Journal of Curriculum and Instruction edited by Ivowi, U.M.O. Enugu, Donze Press

Ministry of Education (2002). Junior Secondary School Examination Question Papers. Igbo Language .Lagos: Ministry of Education.

Isaac, S. \& Micheal, W.B. (1983).Handbook in Research and Evaluation. San Diego Califonia: EDTS Publishers.

Kubr, M. \& Prokopenko, J. (1989).Diagnosing Management Training and Developmental Needs: Concept and Techniques. Geneva: International Labour Organisation.

Leatherman, D. (1990). The Training Trilogy: Assessing Needs. Amherst, Massachusett: HRD Press Inc. Nworgu,B. G.(1991).Educational Research. Basic Issues and Methodology. Ibadan: Wisdom Publishers.

Obe, E. O. (1980). Educational Testing in West Africa. Lagos: Premiere Press and Publishers.

Ohiri - Aniche C. (2000)."Nigerian Languages in $21^{\text {st }}$ Century:What vision." In Ogbulogo,C., Alaba,G. and Ezikeojiaku, P.(eds.) Advances in African Languages and Culture(pp 61 - 75) Lagos; Orient Publishers.

Valette, R.M. (1967).Modern Language Testing. New York: Harcourt Brace Jovanovich. 